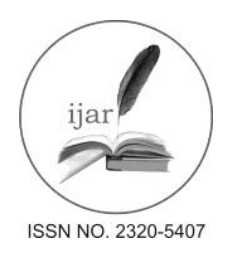

Journal homepage: http://www.journalijar.com
Journal DOI: 10.21474/IJAR01

INTERNATIONAL JOURNAL

RESEARCH ARTICLE

\title{
A NEED OF IN-SERVICE ENGLISH LANGUAGE TEACHER TRAINING PROGRAMME IN ALIGARH MADRASAS: A CASE STUDY.
}

Noor Rizvi.

Research scholar, Department of English Language Teaching, AMU, Aligarh-202002 (U.P.), India.

\section{Manuscript Info}

Manuscript History:

Received: 19 March 2016

Final Accepted: 26 April 2016

Published Online: May 2016

Key words:

Teacher training, In-service teacher training, Madrasa. .

*Corresponding Author

..........................

Noor Rizvi.

\begin{abstract}
Education is a life-long process. The teacher should continue to learn throughout his life. The International Commission on Education has further strengthened the need of in-service training program by giving a new concept of life-long education. This report states, "Every individual must be in a position to keep learning throughout his life. The idea of life-long education is the key-stone of the learning society." In service teacher training is also a way of updating teacher's skills and knowledge for improving teaching and learning which lead to better job performance. It is important for teachers to face new challenges and changes in the education world. It helps in fundamental aspect to improve teacher professionalism. This paper discusses the need for in-service training for teachers at Madrasas in Aligarh district of Uttar Pradesh. Research is based on the primary data which is collected through questionnaire and interview.
\end{abstract}

Copy Right, IJAR, 2016. All rights reserved.

\section{Introduction:-}

Education is a life-long process. The teacher should continue to learn throughout his life. The International Commission on Education has further strengthened the need of in-service training program by giving a new concept of life-long education. This report states, "Every individual must be in a position to keep learning throughout his life. The idea of life-long education is the key-stone of the learning society." According to a recent report Literacy rates among Muslim community are 41.27 per cent against the national rate of 63.07 per cent .Madrasas are doing constructive work. They are providing education to millions of literate, poor muslims which the government has failed to do.

Definition of Madarsa:- "Madrasa is an institution of learning where Islamic sciences including literary and philosophical ones are taught" (Encyclopedia of Islam-Lei den E.J.Brill). The aim of Madrasa education is to inculcate the belief and practice of Islam among its followers and guide them to follow Quran and tradition of the Prophet. It is clear that Madrasa education system has produced many international fame scholars but majority of taliba (students) are lacking in jobs.

\section{Literature review:-}

In service teacher training is also a way of updating teacher's skills and knowledge for improving teaching and learning which lead to better job performance. It is important for teachers to face new challenges and changes in the education world. It helps in fundamental aspect to improve teacher professionalism.

* According to Sachar committee report "It had said community was lagging behind in modern education". There are quite a few Madrasas in the country, where courses in computerization and other modern skills were being imparted.

* A lot of policies and commission had highlighted the modernization of Madrasa in it like NPE (National policy of education, 1985) and SPQEM (Sponsored Scheme for Providing Quality Education in Madrasa, 2013). 
* The National Monitoring Committee for Minorities Education (NMCME, 2004) was constituted to improve the conditions for educational empowerment of minorities.

* An Expert Committee of the NMCME was revising the programme of modernization of Madrasas The Expert Committee has given suggestion that Madrasas be provided a linkage with the National Institute of Open Schooling (NIOS) to provide for certification of academic levels, linkages with vocational education, improving the quality of education in modern subjects, introduced teacher training, enhancement of teacher salaries, raising awareness about education programmes for the Muslim community.

* Moving one step further on 'Sabka sath sabka vikas'(together with all development for all, 2015) , government of India in its maiden budget allocated Rs 100 crore for modernization of Madrasa, with the aim to upgrade skills of minorities in the traditional art and crafts.

The problem came from ignorance of English in Madrasas, but now changes are very clear as English is taught in many Madrasas in India. So here need to encourage traditional institution like Madrasa \& Maktabs and give more focus on their present needs and improve their quality in terms of Teacher development programme and in-service teacher training which helps in their practice. Role of teacher in modern teaching-learning students has become are expected to be change agent and take up new challenges. In order to meet these challenges teacher require continuous training and development. Therefore the training and in-service training is crucial and important. The expression in-service training refers to training of teachers who are already in-service. In-service training include everything from the day teacher join the institution and he retires. The situation even makes more critical when we find that Madrasa in-service teachers are untrained. The term 'need' has been used to denote the gap existing between the current status and the desired one or the required level of competencies.

Need of the study:- Madarsa plays essential role in the education system. Teachers training will improve the quality of teachers and their way of teaching abilities. Most of the madarsas are deprive from the basic needs of education. There is relatively scarcity of research related to Madarsa education, so the present study will aim to evaluate in service teachers training and problems faced by teachers in Aligarh district.

Aim of the study:- This study aims to assess the needs of in-service teacher training in Madrasa of Aligarh and find out the problems faced by English Teachers.

\footnotetext{
Objectives:-

* To analyze the need of in-service teacher training program in Madarsas.

* To find out the problems faced by English teachers in Madarsa.

* To suggest some remedial measures for improvement of their needs.
}

\section{Hypothesis:-}

The hypothesis of the study is that there has no significant impact of in service teacher training programme in Madaras education.

\section{Research design and methodology:-}

Venue of the study: This subject of the study is taken from three selective Madrasas in Aligarh.

1. Tamir-a-Millat Islamia Inter College, Dodhpur, Aligarh,

2. Madrasa Lutfia Arabia Upper koat, Aligarh and

3. Madinatul Uloom Collage in Dhorra Mafi, Aligarh.

At the first round, the entire three Madrasas of Aligarh district were visited to collect the preliminary information on the question related to in-service teacher training program by questionnaires.

The second round of the field survey was more selective in form of semi-structured interview as we concentrated to the teacher needs related to in-service teacher training programme, and looking forward their suggestion

Research design:- The present study is based entirely on the primarily data collected through questionnaire and interview. Case Study has taken as a method of study.

Sampling method:- Samples were selected by using the questionnaire and interview method. 
Sample Size:- The total strength of class is 70-80 in each Madrasas (Approximate) in IX and X. Four English teachers has taken from each Madrasa,total number of teachers are 12. All are recognized by Uttar Pradesh Madrasa Board. English course and syllabus is based on Board of High School \& Intermediate Education, Allahabad, Uttar Pradesh. There are 2 textbooks for teaching English (New Light, General English and English by Gupta \& Upadhyay)

\section{Results and Discussion:-}

Teacher's views concerning the in-service training course (questionnaire)

Have you heard in-service teacher training programme?

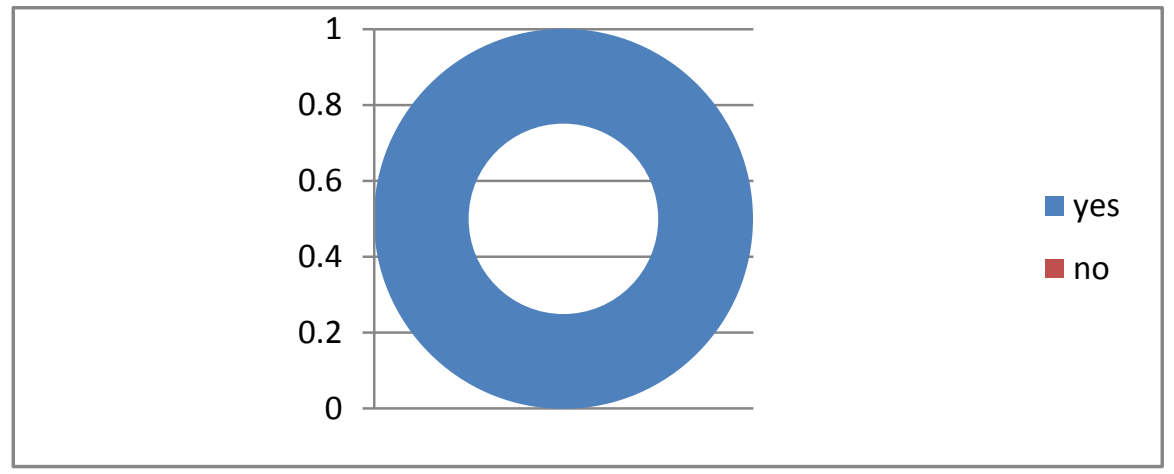

From above figure it is very clear that all in-service English teachers are familiar by in-service teacher training programme.

How many in-service training programme(s) have you attended?

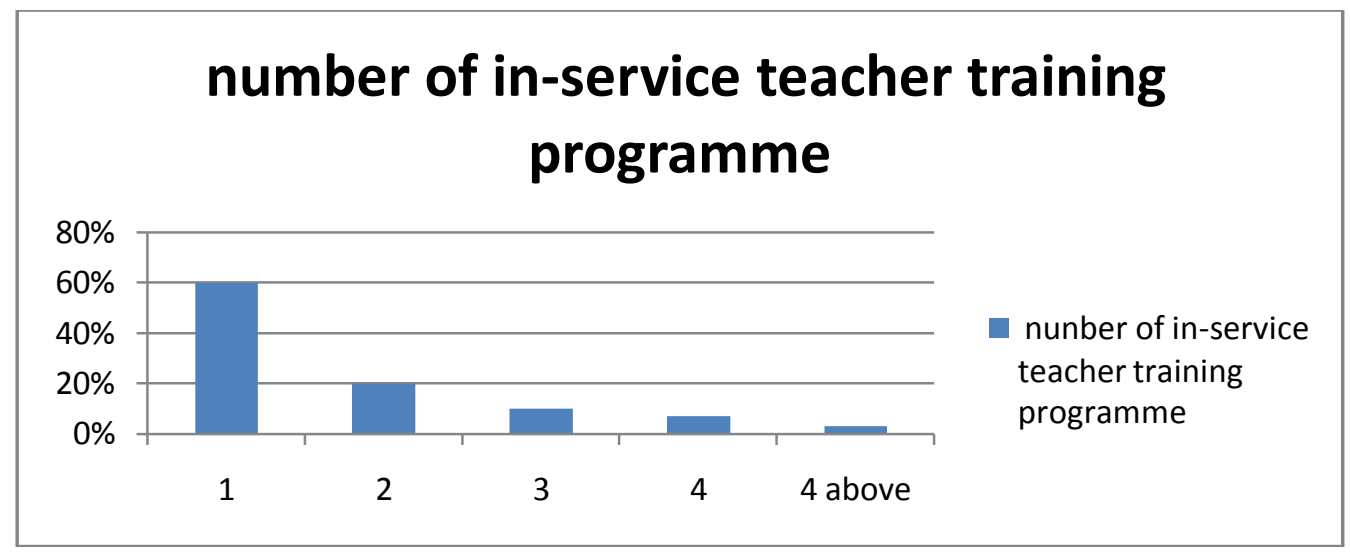

The above table shows that out of 20 in-service English teachers in Madrasa (60\%) teachers have done 1 in-service teacher training programme $(40 \%)$ teachers have done 2 in-service teacher training programmes $(10 \%)$ teachers have done 3 programmes and only (3\%) teachers have done more than 3 in-service teacher training programmes. 
Is In- service training contribute to your professional development?

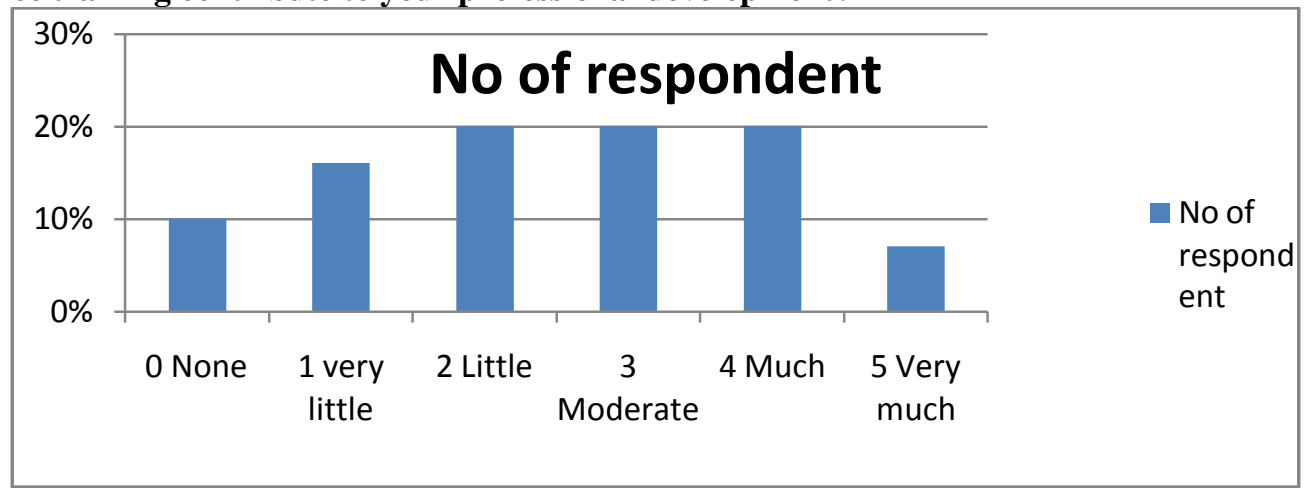

From the above given figure it is clear that most the teachers are agreed that in-service teacher training contribute in their professional development.

Is In-service teacher training update your knowledge?

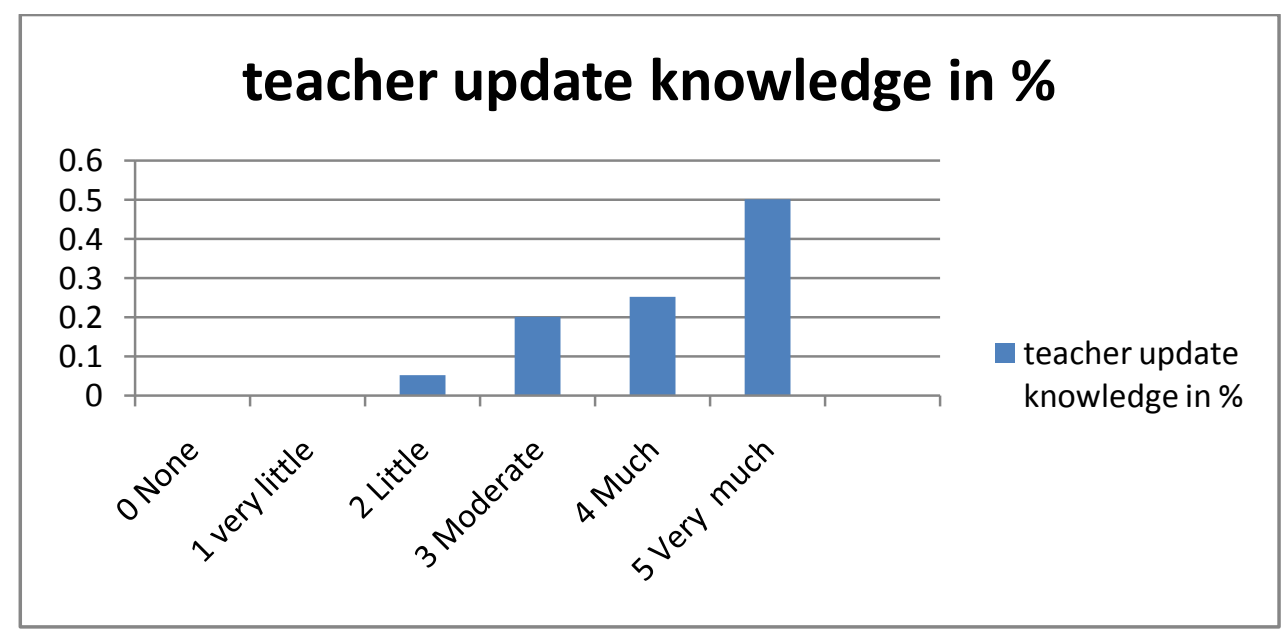

The above table shows that most of the teachers are positive about In-service teacher training program will update their knowledge, as 30\% teachers are strongly agreed, and $25 \%$ are agree about that.

Rate your need for in-service training programme in language skills (LSRW)?

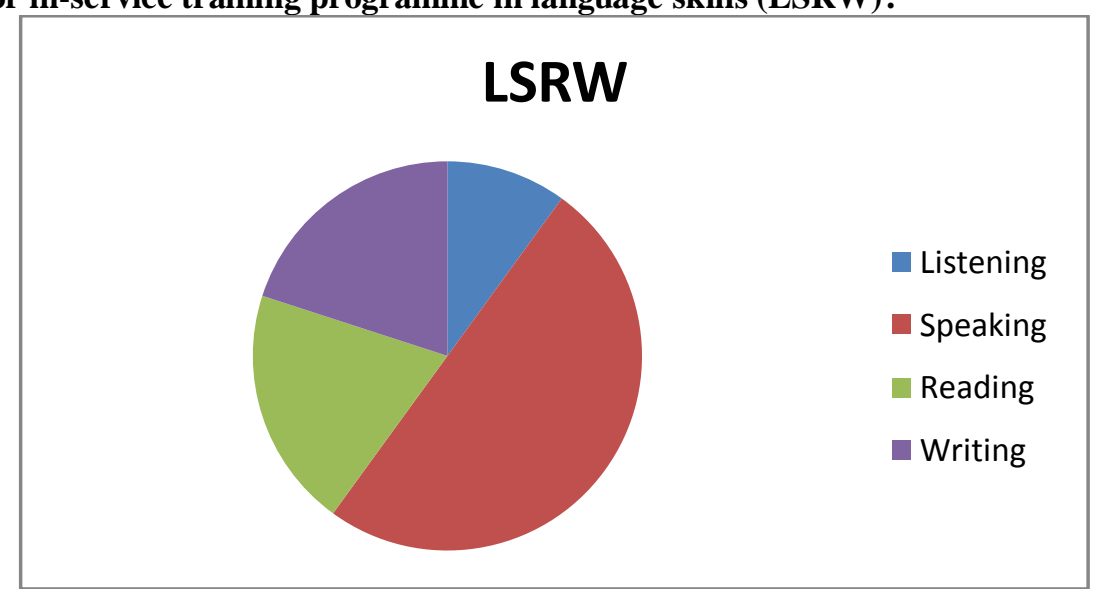


Under four language skills, most of the in-service teachers need in speaking is $(60 \%)$ other important language skills are reading (20\%), writing (20\%) and followed by listening (10\%).

What forms of training programs would you consider more useful for secondary school teacher in your Madrasa?

\title{
In-service training programme
}

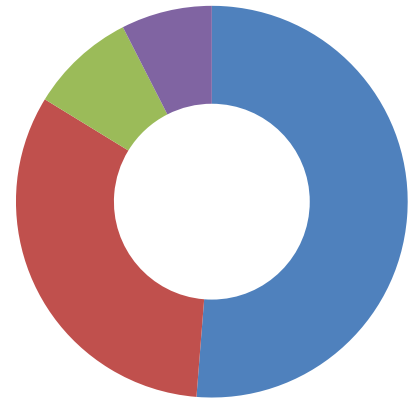

\author{
workshop \\ refresher course \\ classroom observation \\ other suggestions
}

Madrasas in-service teacher suggests wants more workshops and refresher courses, some teachers suggests that workshop should conduct in appropriate timmings, so they can attend it. Workshop and refresher courses will focus on new issues in teaching pedagogy.

Teachers views concerning the in-service training course (Interview):-

While Interview with Madrasa teachers, they talked about various misconception about Madrasa,and talked its role in promoting education in masses. They also talked about their students who are in job and successful in their career.Madrasa in-service teachers suggests some important suggestion and their needs which they are lacking in their respective institutions.

1.

\begin{tabular}{|l|l|}
\hline Name of the respondent & Md. Shafiqur Rahman \\
\hline Madarsa Name & Tamir-a-Millat Islamia Inter College, Dodhpur, Aligarh \\
\hline Teaching Experience & 10 years \\
\hline Qualification & M.A.(English), B.Ed. \\
\hline & \\
\hline
\end{tabular}

The first important issue which was discussed by Respondent (1) most of the in-service teachers was use of technology has been introduced in their classrooms. As English is compulsory part of their course, they eager to use multimedia materials while teaching language skills. He and another Madrasa teachers also discussed that they are not conversant with computers; they need more trainings in that particular areas.

2.

\begin{tabular}{|l|l|}
\hline Name of the respondent & Mrs. Asma Khatoon \\
\hline Madarsa Name & Madrasa Lutfia Arabia Upper koat, Aligarh \\
\hline Teaching Experience & 6 years \\
\hline Qualification & B.A. (English), Diploma in teaching \\
\hline
\end{tabular}

She was discussing about the syllabus and textbook, which mostly includes exercises based on box items, pictures and cartoons. She also talked about every teacher, has certain difficulties regarding syllabus which has some changes and also topics which is not so much clear for them. In-service training will try to remove such difficulty.

3.

\begin{tabular}{|l|l|}
\hline Name of the respondent & Mrs. Nishat Fatima \\
\hline Madarsa Name & Madinatul Uloom Collage in Dhorra Mafi, Aligarh \\
\hline Teaching Experience & 12 years \\
\hline Qualification & M.A. (English), B.ed. \\
\hline
\end{tabular}


She said that there is a demand of practical aspects like communication and speaking skills. It will increase employability skills of pupils. It will require in in-service training of the teachers.

\section{Conclusion:-}

Aligarh is a Muslim majority district having a large number of Madrasa through knowledge is imparted to the local people .It is clear that many of the student's destinies lie in hands of Madrasa. In many Madrasa in Aligarh religious and modern education is teaching along with English. From above data collected through questionnaire and interview and discussion with in-service teachers in Madrasa of Aligarh, most of the teacher in Madrsa have done in-service teacher training and they need more in-service teacher training programme in form of workshop and refreshers courses for their professional development.

\section{Limitation of the study:-}

1. The sample size of study was small and hence the generalization of the result remains doubtful.

2. There were difficulty in collecting data from Madarsas because they enquired a lot about the researcher and the purpose of the study.

3. In initial visits Madarsa Teachers had problem in interaction but after random visits they build a strong rapport and cooperate with the researcher.

\section{Future directions and recommendations:-}

Their further suggestions related to training programme are duration of workshop should be 10-15 days, so they can better train in that. They suggest that there is more in-service programme for English Teachers in Madarsa School. Madrasa English Teachers also talked about curriculum for secondary school level, Latest Methods like Communicative Language Teaching should be incorporated and taught so that the students are not lagging behind. The curriculum can be modified only with support of teacher's .Accordingly the teachers should train in this field of curriculum in advance so that it is acceptable. Madrasa teachers strongly recommend that use of technology should be in-cooperated with language teaching, so that student can practically train in multimedia tools used in language.

\section{References:-}

* Ahmad, Manzoor (1990) Islamic Education: Redefinition of Aims and Methodology, New Delhi: Genuine Publications.

* Encyclopaedia of Islam, New Edition, edited by P.J. Bearman, Th. Bianquis, C.E. Bosworth, E. van Donzel and W.P. Heinrichs.

* Indian-state-derecognises-madrassa-education www.aljazeeranews.com.

* NPE (National policy of education), 1986 www.ncert.nic.in.

- Qureshi M.H. (March 2014) Challenges before madrasa teachers and their in-service training at elementary level of education, Excellence International Journal of Education and Research journal.

* Sabka sath sabka vikas', 2015, scheme by government of India m.timesof india.com.

* Sachar committee report, 2005 www.minorityaffairs.gov.in.

* SPQEM (sponsored scheme for providing quality education in Madrasa) www.imass.org.in.

* The National Monitoring Committee for Minorities Education (NMCME),2004 